Article

\title{
Energy Performance and Thermal Comfort of a High Efficiency House: RhOME for denCity, Winner of Solar Decathlon Europe 2014
}

\section{Gabriele Battista $^{1, *}$, Emiliano Carnielo ${ }^{1}$, Luca Evangelisti ${ }^{1}$, Marco Frascarolo ${ }^{2}$ and Roberto de Lieto Vollaro ${ }^{1}$}

1 Engineering Department, University of Roma TRE, Via della Vasca Navale 79/81, Rome 00146, Italy; E-Mails: emiliano.carnielo@uniroma3.it (E.C.); luca.evangelisti@uniroma3.it (L.E.); roberto.delietovollaro@uniroma3.it (R.L.V.)

2 Architecture Department, University of Roma TRE, Via della Madonna dei Monti 40, Rome 00184, Italy; E-Mail: marco.frascarolo@uniroma3.it

* Author to whom correspondence should be addressed; E-Mail: gabriele.battista@uniroma3.it; Tel.: +39-06-5733-3289.

Academic Editors: Francesco Asdrubali and Pietro Buzzini

Received: 4 June 2015 / Accepted: 14 July 2015 / Published: 17 July 2015

\begin{abstract}
The increase of people living in large cities and the expansion of new urban areas are keys to defining new sustainable models. It is estimated that about $70 \%$ of the EU population lives in urban areas, and it is expected to reach $80 \%$ by 2030 . Consequently, it is important to find a new concept of buildings that can reduce the total energy consumption. The Solar Decathlon is an international university competition, born in 2002, created by the U.S. State Energy Department (DOE). Students are challenged to design and operate a full-scale, innovative and sustainable house able to exploit solar radiation as its sole energy source. The objective of the competition is to promote research and education in sustainable architecture and solar energy fields. This paper presents an overview on the contribution of LIFT (Interdisciplinary Laboratory of Technical Physics of Roma Tre University) to the winning project of the Solar Decathlon Europe 2014 competition: The RhOME for denCity. This project consists of a building properly designed to produce a solar-powered house that is cost-effective, energy-efficient, and attractive.
\end{abstract}

Keywords: solar decathlon; near zero energy buildings; energy efficiency 


\section{Introduction}

During the last few decades, the availability, cost and sustainability of the energy resources have caused instabilities in the energy production and distribution chain. Moreover, environmental damage has shown the need for new energy models. The rapid increase of the electricity demand is a general constant around the world. This growth responds to various reasons, among which the increasing awareness of global warming caused by greenhouse emissions stand out, the inevitable exhaustion of traditional energy sources in the following decades (fossil fuels) and the need for countries to assure energy self-dependence [1,2]. The building sector and people activities in buildings are responsible for approximately $31 \%$ of the global final energy demand, one-third of the energy-related $\mathrm{CO}_{2}$ emissions, two-thirds of the halocarbon emissions, $25 \%-33 \%$ of black carbon emissions and almost $60 \%$ of the world's electricity consumption [3]. Therefore, investments in new energy infrastructures and grid improvements must be achieved [4], which is of particular significance in the European Union context, where new buildings will have to be nearly zero energy buildings (nearlyZEB's) from 2020 [5,6].

Solar Decathlon is an international competition open to universities and collegiate institutions around the world, giving them the opportunity to compete for a target: to design and build a solar house that is energy independent [7-10]. It takes place in odd years in the USA. Since 2010, the Solar Decathlon is also held in Europe in even years.

The project Solar Decathlon was founded in 2002, thanks to the U.S. Energy Department (DOE) [11]. It is aimed at enhancing and accelerating the spread of a sustainable culture, raising public awareness and institutions on the impact that design and construction of buildings have on citizens' life quality and providing clear benchmarks to the industries as well as encouraging a productive competition.

During the competition, the energy consumed by each house is generated using solar energy solutions. The competition assesses the team's ability to conserve energy, control the physical environment in the home and demonstrate full energy sufficiency [12].

The scientific objective of Solar Decathlon is to refine the knowledge, research and experimentation about the renewable energy field and, in particular, solar energy [13]. Furthermore, the competition is an opportunity to present to the public designs concerning solar-powered houses, gather ideas to use in their own homes, and learn how energy-saving features can help them with economic savings.

During the 2014 edition that took place in Versailles (France), 20 teams were selected. The teams are challenged to design and operate a full-scale, innovative and sustainable house also able to exploit solar radiation. Projects are evaluated according to ten criteria:

(1) Architecture: Assess design coherence, flexibility and maximization of space, technologies and bioclimatic strategies;

(2) Energy Efficiency: Consider excellence in systems and house design, while looking for reduction of energy consumption;

(3) Comfort Conditions: Consider the capacity for providing interior comfort through the control of temperature, humidity, acoustic, lighting and quality of interior air;

(4) Communication \& Social Awareness: Assess the team's capacity to find creative, effective and efficient ways of transmitting ideas that define the teams' and projects' own identity;

(5) Innovation: Estimate the innovative aspects of houses in preceding contests, focusing on changes that impact value, performance or efficiency; 
(6) Engineering \& Construction: Evaluate functionality of the house structure, envelope, electricity, plumbing and solar system;

(7) Electrical Energy Balance: Measure the houses' electrical energy self-sufficiency and efficiency and assessment of their energy balance;

(8) House Functioning: Evaluate the functionality and efficiency of a set of appliances that must comply with the demanding standards of present-day society;

(9) Urban design, Transportation \& Affordability: Evaluate the relevance of the housing unit's grouping proposal and regional positioning, with regard for social and urban contexts of the project;

(10) Sustainability: Measure the team's reactivity to environmental issues, including its efforts to attain a maximum reduction of negative environmental impact.

The following Table 1 shows the scores awarded according to the ten criteria previously reported for the projects submitted by the 20 teams in the 2014 Solar Decathlon contest.

The paper presents an overview on the RhOME for denCity project, the competition winner, which has been designed by a multidisciplinary team of Roma TRE University [14]. The project goal was to achieve a solar-powered, cost-effective, energy-efficient, and attractiveresidential building.

Moreover, the paper reports about the contribution of LIFT (Interdisciplinary Laboratory of Technical Physics) for the winning project.

\section{Case Study}

The structure of RhOME for denCity shown in Figure 1 is part of an extended building project that consists of many innovative apartments. The first step of the project was to replace an old building stock in Torre del Fiscale with the RhOME for denCity building. The project is focused on the urban fragmented environment, where the basic services and the hierarchy of spaces are missing. Furthermore, there is the need to protect the cultural and historical heritage. The residential units which were built with uncertified quality materials, as well as located in a position which is not in accordance with the landscape constraints, will be demolished. For the buildings that will be restored, their functions will be preserved, only when their activities are to be essential activities for the district, such as religious activities. For buildings with historical/cultural importance, the inclusion of new features is planned so that it would evoke the ancient characters.

Considering the building shown in Figure 2, it is possible to identify four floors each of them composed by two apartments with different sizes and a stairwell in the middle: The first floor consists of two apartments with an area of $93 \mathrm{~m}^{2}$ and $78 \mathrm{~m}^{2}$; the second one consists of two apartments with an area of $68 \mathrm{~m}^{2}$ and $103 \mathrm{~m}^{2}$ respectively; the third one consists of two apartments with an area of $81 \mathrm{~m}^{2}$ and $90 \mathrm{~m}^{2}$; the fourth one consists of two apartments with an area of $93 \mathrm{~m}^{2}$ and $78 \mathrm{~m}^{2}$. The storey height is $2.7 \mathrm{~m}$ and each apartment is composed of a bathroom, kitchen and a utility room. The windows are shaded by a movable shutter or by a fixed element that sticks out from the building. 
Table 1. Team projects scores.

\begin{tabular}{|c|c|c|c|c|c|c|c|c|c|c|c|c|c|c|}
\hline Name & Nation & (1) Arch. & (2) En. Eff. & (3) Comfort & (4) Com. & (5) Innov. & (6) Eng. & (7) Elec. & (8) Funct. & (9) Urban Des. & (10) Sust. & Pen. & Bonus & Tot \\
\hline Philéas & FRA & 102.00 & 80.00 & 101.82 & 52.00 & 62.39 & 70.40 & 79.80 & 107.34 & 96.00 & 74.00 & 0.00 & 14.00 & 839.75 \\
\hline Ressò & SPA & 120.00 & 73.47 & 84.30 & 54.00 & 75.00 & 64.00 & 68.57 & 80.02 & 105.88 & 44.00 & 0.00 & 7.00 & 776.24 \\
\hline EFdeN & ROU & 54.00 & 40.82 & 48.37 & 0.00 & 32.17 & 56.00 & 22.81 & 48.32 & 0.00 & 44.00 & 0.00 & 2.00 & 348.49 \\
\hline RenaiHouse & JPN & 111.60 & 32.65 & 102.17 & 65.00 & 56.20 & 76.00 & 93.19 & 95.10 & 93.18 & 44.00 & 0.00 & 5.00 & 774.09 \\
\hline Home with a skin & NLD & 90.00 & 78.37 & 94.47 & 80.00 & 60.89 & 52.00 & 80.47 & 103.97 & 96.00 & 80.00 & 0.30 & 22.00 & 837.87 \\
\hline Embrace & DNK & 78.00 & 71.84 & 99.23 & 64.00 & 59.81 & 69.90 & 79.22 & 90.66 & 101.65 & 68.00 & 2.00 & 0.00 & 780.31 \\
\hline Casa Fenix & CHL/FRA & 78.00 & 71.84 & 68.48 & 73.00 & 65.08 & 72.00 & 89.62 & 87.70 & 96.00 & 76.00 & 0.30 & 25.00 & 802.42 \\
\hline Techstyle Haus & USA/GER & 78.00 & 71.84 & 107.02 & 67.00 & 51.12 & 52.00 & 19.72 & 102.35 & 49.41 & 52.00 & 0.00 & 7.00 & 657.46 \\
\hline Adaptive House & THA & 72.00 & 32.65 & 76.41 & 44.00 & 46.17 & 48.00 & 34.01 & 73.87 & 28.24 & 56.00 & 3.20 & 0.00 & 508.15 \\
\hline Your+ & CHE & 90.00 & 65.31 & 107.59 & 76.00 & 58.06 & 60.00 & 63.33 & 107.75 & 84.71 & 68.00 & 0.00 & 24.00 & 804.75 \\
\hline CASA & MEX & 102.00 & 61.22 & 67.26 & 60.00 & 63.95 & 80.00 & 76.50 & 60.30 & 112.94 & 74.00 & 2.00 & 4.00 & 760.17 \\
\hline OnTop & GER & 90.00 & 73.47 & 104.81 & 59.00 & 55.26 & 60.00 & 83.62 & 102.34 & 84.71 & 60.00 & 1.50 & 22.00 & 793.71 \\
\hline Liv-Lib' & FRA & 54.00 & 32.65 & 55.91 & 0.00 & 33.08 & 0.00 & 22.02 & 41.97 & 21.18 & 16.00 & 8.00 & 0.00 & 268.81 \\
\hline Symbcity & SPA & 66.00 & 76.73 & 103.40 & 71.00 & 52.51 & 32.00 & 53.21 & 63.68 & 81.88 & 48.00 & 0.00 & 2.00 & 650.41 \\
\hline Maison Reciprocity & USA/FRA & 90.00 & 65.31 & 94.29 & 71.00 & 57.67 & 52.00 & 101.75 & 91.02 & 81.88 & 56.00 & 0.00 & 16.00 & 776.92 \\
\hline RoofTop & GER & 111.60 & 73.47 & 96.26 & 56.00 & 64.31 & 70.40 & 77.42 & 104.14 & 98.82 & 56.00 & 2.00 & 17.00 & 823.42 \\
\hline Rhome for DenCity & ITA & 114.00 & 73.47 & 107.40 & 61.00 & 71.81 & 67.20 & 58.41 & 108.60 & 84.71 & 70.00 & 0.00 & 24.00 & 840.60 \\
\hline H Naught & IND & 54.00 & 32.65 & 48.70 & 0.00 & 47.00 & 56.00 & 63.50 & 67.10 & 42.35 & 48.00 & 7.00 & 0.00 & 452.30 \\
\hline Tropika & CRI & 66.00 & 65.31 & 52.57 & 55.00 & 54.06 & 69.60 & 15.00 & 70.44 & 74.82 & 64.00 & 4.00 & 6.00 & 588.80 \\
\hline Orchid House & TWN & 102.00 & 76.73 & 77.05 & 62.00 & 72.25 & 71.20 & 28.70 & 92.72 & 120.00 & 64.00 & 4.50 & 10.00 & 772.15 \\
\hline \multicolumn{2}{|c|}{ Maximum Value } & 120 & 80 & 120 & 80 & 80 & 80 & 120 & 120 & 120 & 80 & & & \\
\hline
\end{tabular}




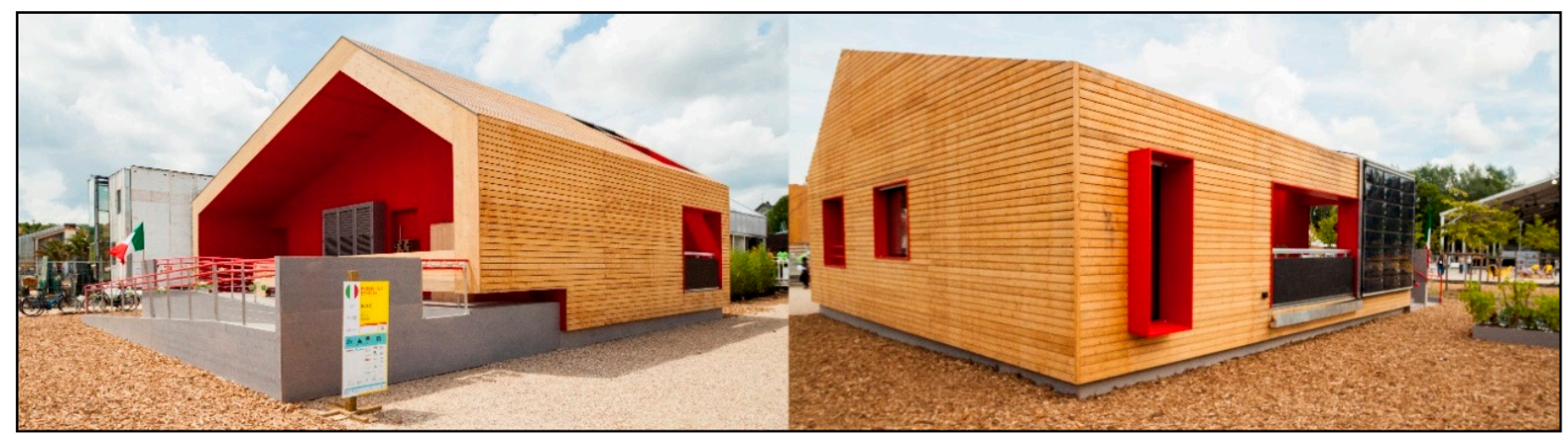

Figure 1. RhOME for denCity house.
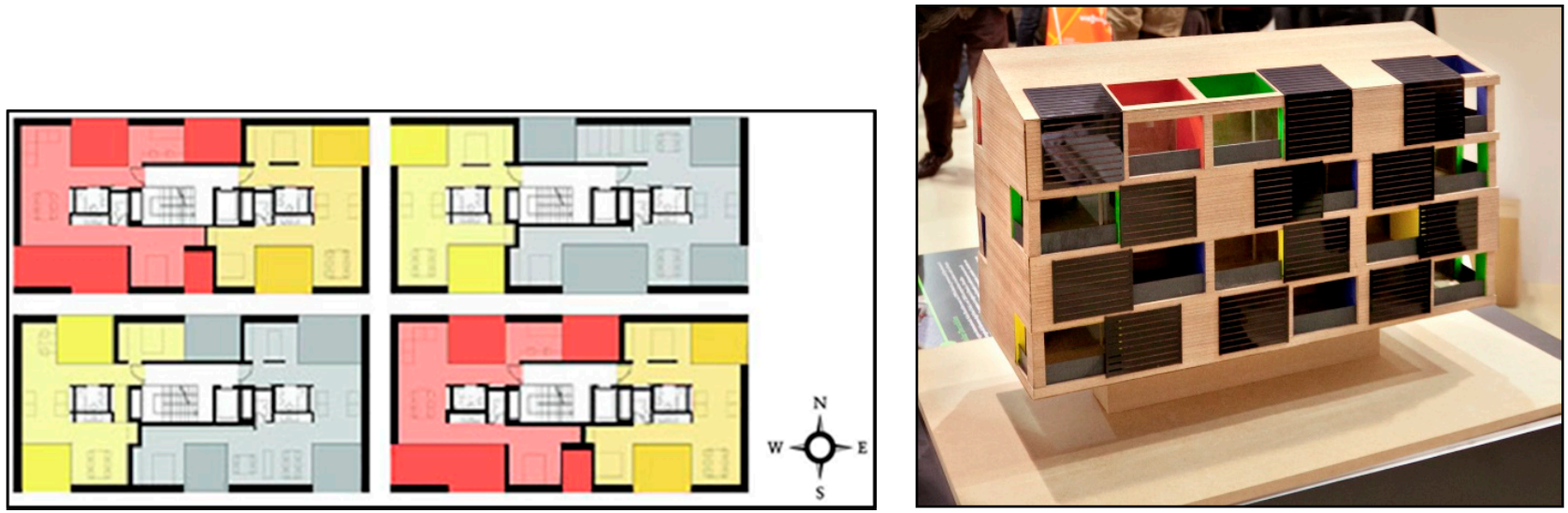

Figure 2. Building layout.

The final aim of the designed building is to exploit the inertial wall characteristics. The project idea starts from the sustainability, modularity and prefabrication of each building element. This purpose is achieved by exploiting properly chosen materials and technology through which it is possible to reduce the building impact on the environment. For these purposes, a dry and lightweight prefabricated element has been used, and, in some cases, pre-assembled. The building is composed of a wood envelope with movable screens, loggias, balconies and large wall thickness for taking advantage of thermal inertia proprieties.

The building envelope characteristics have been designed for optimising the inside air temperature control. Indeed, the stratigraphy of the building envelope was properly chosen in order to minimise the effects of the external temperature fluctuation. Furthermore, the prefabricated elements aim at reducing the thermal bridges' effects. The roof, as it can be seen in Figure 3a, presents a thickness of $39.3 \mathrm{~cm}$ and it is externally wood covered. The thermal insulation is ensured through a high-density wood fibre (low thermal conductivity) and Oriented Strand Board (OSB) panels. The floor thickness is $46.8 \mathrm{~cm}$ (Figure $3 b$ ) and it is composed of a low-density wood fibre and OSB panels. Unlike the roof stratigraphy, the floor includes a cork layer which is a natural and breathable material with excellent thermal-acoustic insulation proprieties. 


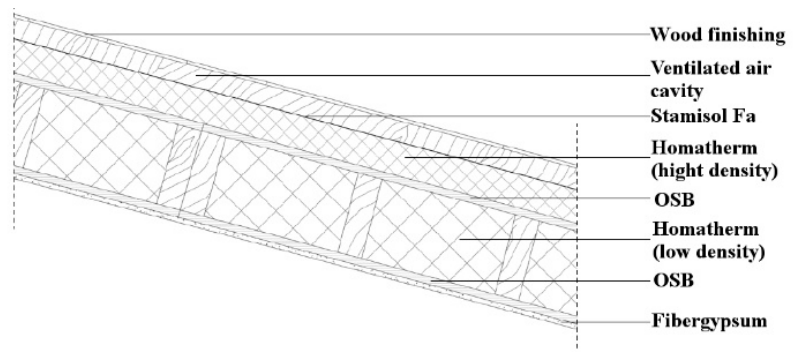

(a)

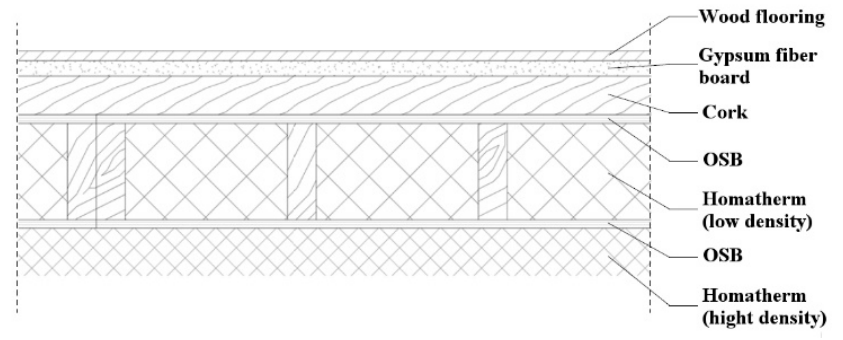

(b)

Figure 3. (a) Roof stratigraphy; (b) Floor stratigraphy.

The external wall shown in Figure 4 a has a thickness of $39.9 \mathrm{~cm}$. Starting from the external layer, it is possible to observe a thermal high-density insulation layer, a low-density insulation layer and a wet sand layer separated by plaster fibre layers. Wet sand works like a thermal accumulator by converting the thermal power entering in the wall in evaporation latent heat.

The internal wall is characterised by a total thickness of $39.3 \mathrm{~cm}$, as it can be seen in Figure $4 \mathrm{~b}$. This component does not present the wet sand layer because it is used solely as a room divider.

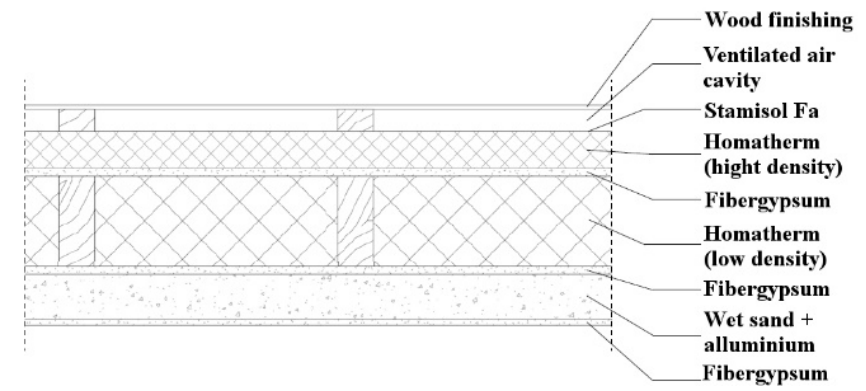

(a)

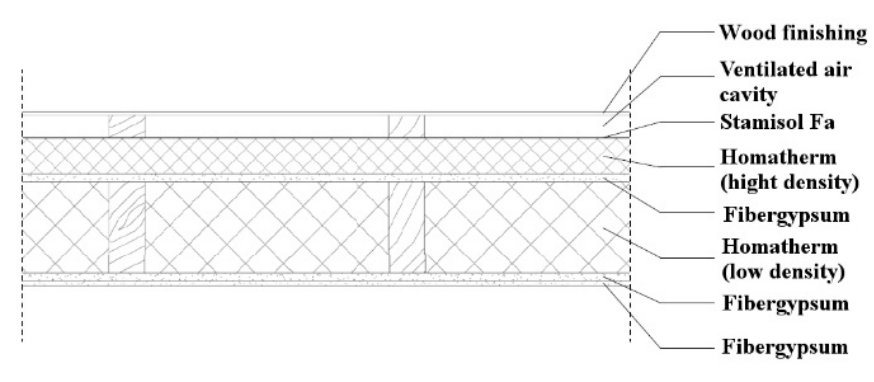

(b)

Figure 4. (a) External wall stratigraphy; (b) Internal wall stratigraphy.

All chosen materials and their assembly allow one to obtain a house characterised by low thermal energy transmittance. The transmittance value of the building's opaque components is reported in Table 2.

Table 2. Transmittance value of the building elements.

\begin{tabular}{ccc}
\hline Opaque Component & Thickness $(\mathbf{c m})$ & Thermal Transmittance $\left(\mathbf{W} / \mathbf{m}^{\mathbf{2}} \mathbf{K}\right)$ \\
\hline Roof & 39.3 & 0.122 \\
Floor & 46.8 & 0.100 \\
External wall & 39.9 & 0.123 \\
Internal wall & 39.3 & 0.125 \\
\hline
\end{tabular}

The transparent components are characterised by double insulated glazing of 4/16/4 with krypton. The transmittance is $0.86 \mathrm{~W} / \mathrm{m}^{2} \mathrm{~K}$ and the g-value is 0.598 . 


\section{Passive Solutions}

During summer, the sliding/tilting screen system showed in Figure 5 shades the window, decreasing the entering solar gains. As shown in Figure 6, the sand layer is used as an absorber of the internal heat gains produced by occupancy and equipment releasing the stored heat toward the external environment during the night by means of a cross ventilation strategy. The last is obtained by shifting the screen system in order to have the possibility of opening the window entirely.

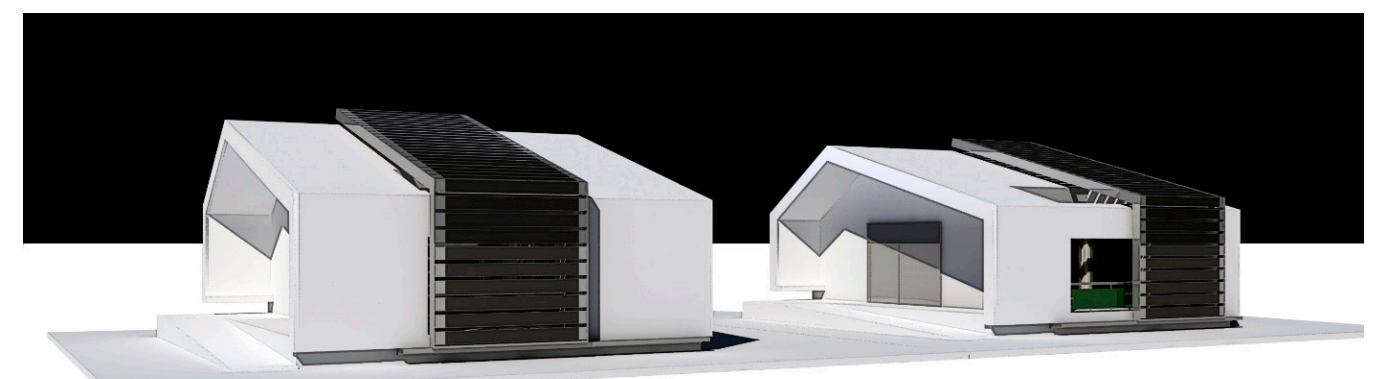

Figure 5. Sliding/tilting screen system.

Figure 6 also shows the distance between the pitched roof and the sliding system containing the PV panels, allowing for the induction of convective air movement in order to cool down the panels.
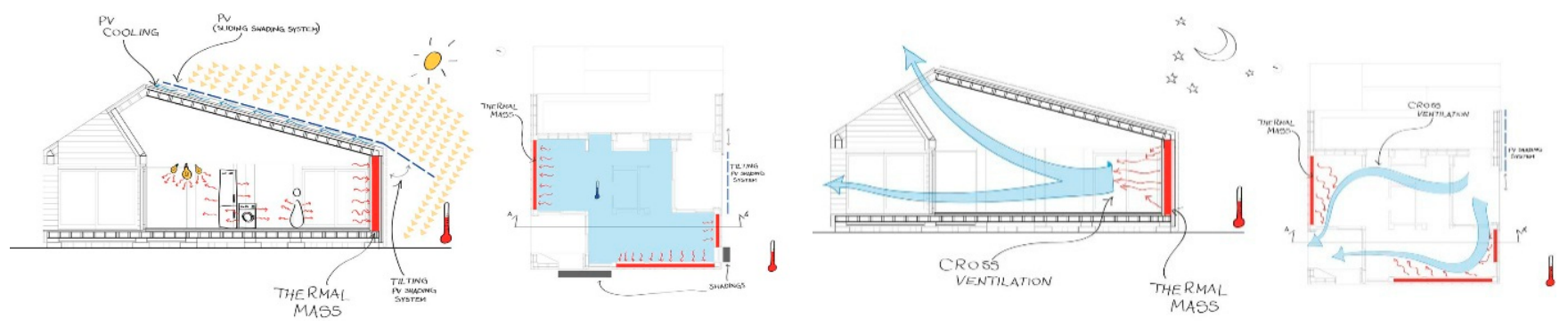

Figure 6. Passive systems in summer.

During winter, the window is not shaded by the PV panel in order to exploit the contribution of solar gains to heat up the internal environment. This heat load together with internal gains is stored in the sand layer during daylight and internally released during the night. The process is reported in Figure 7.
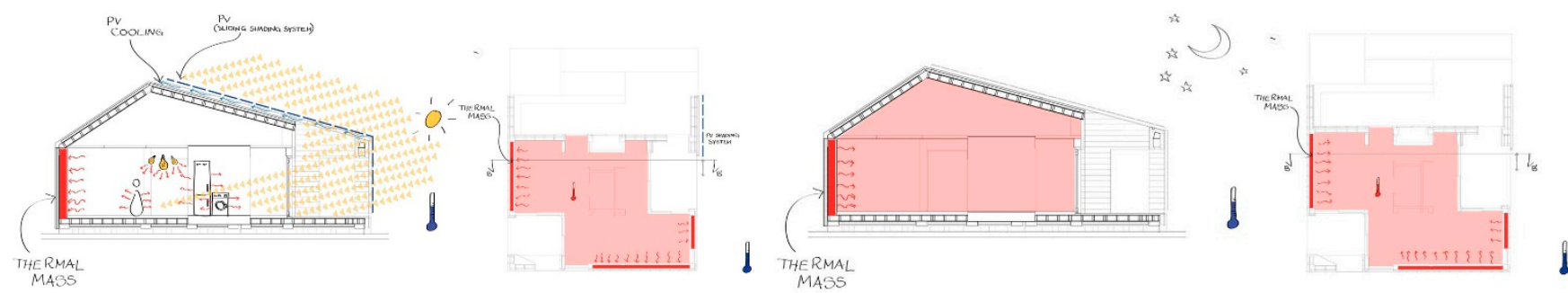

Figure 7. Passive systems in summer. 


\section{House Energy Performance}

The activities carried out by the L.I.F.T. (Interdisciplinary Laboratory of Technical Physics) in the RhOME for denCity project concern the assessment and verification of the energy performances and the building-plant coupling by means of a numerical analysis based on an integrated approach. Moreover, a CFD (Computational Fluid-Dynamic) analysis was performed in order to assess the internal comfort conditions.

\subsection{Plant Feasibility}

The first step of this study refers to the entire building shown in Figure 2. It presents an integrated methodology able to identify the best plant configuration from a technical, economic and environmental point of view. The methodology studied by De Lieto Vollaro et al. [15] is based on two validated calculation tools: TRNSYS and RETScreen. This approach allows an analysis of feasibility, and it starts with the building energy demand analysis, conducted under dynamic conditions through TRNSYS software [16-28]. Simplified methodologies, characterised by semi-stationary conditions, cannot faithfully reproduce the variation of climatic conditions and inertial properties of the structures [29]. Through TRNSYS employment, it is possible to obtain accurate results that allow one to achieve the correct Building-Plant coupling.

Output data obtained by TRNSYS were used as inputs for RETScreen application. RETScreen is a Clean Energy Management Software for energy efficiency, renewable energy and cogeneration project feasibility analysis [30].

Results and Discussion

Due to the residential destination use of the building, the Rome weather data were used in TRNSYS. Set points are: $20^{\circ} \mathrm{C}$ during winter and $26^{\circ} \mathrm{C}$ during summer.

The monthly average energy loads for buildings' heating, cooling and electrical power are shown in Figure 8 .

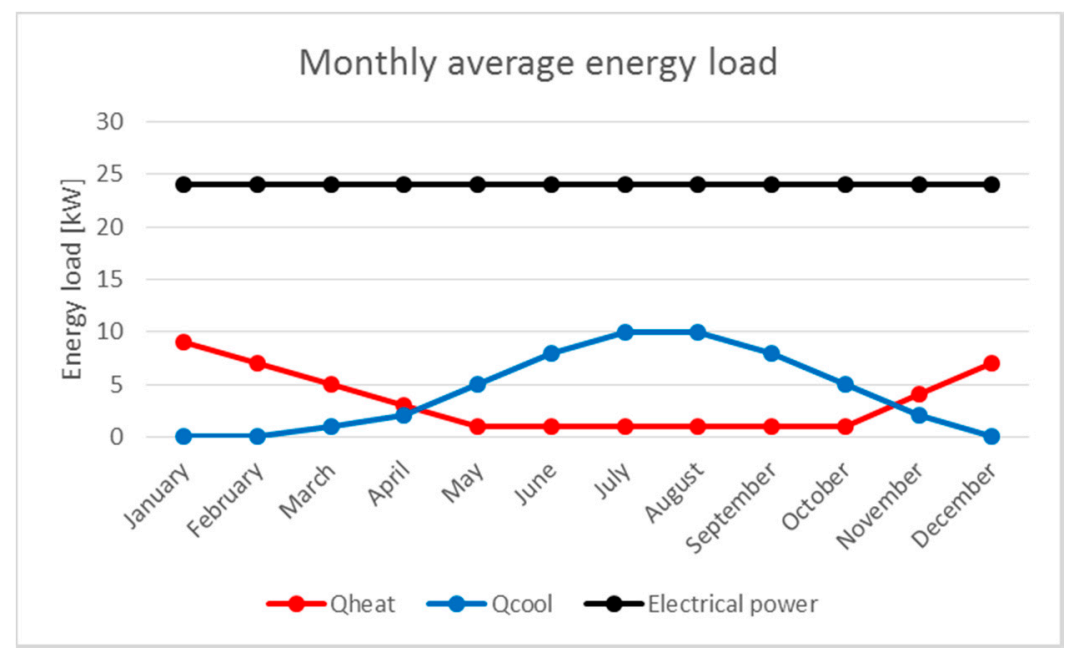

Figure 8. Monthly average energy load. 
The RETScreen tool allows the modelling of many systems for the analysis of the technical, economic and environmental impact. This tool allows one to analyse the greenhouse gas emissions reduction due to the substitution of a conventional heating and cooling system typically used in a residential building with a system composed by more effective elements and powered by renewable energies. In this study, the tool was used to assess the feasibility of a system composed of a heat pump of $20.4 \mathrm{~kW}$ with an energy efficiency ratio (EER) of four for cooling demand, a photovoltaic plant of $5 \mathrm{~kW}$ peak power for the electrical demand and pellet boiler of $30 \mathrm{~kW}$ for heating demand, compared with a conventional technology. The conventional scenario is referred to a system that uses a gas boiler for heating season and a heat pump powered by the Italian electric network.

In the model, all cost items, such as initial, management and annual maintenance costs have been considered. The financial plan was calculated for a 15 year project life, taking into account the current financial parameters (inflation rate, discount rate and rate of indexation of fuel). The return on investments turns out to be positive and linearly increases after the fifth year with a cash flow higher than $350,000 €$.

Tables 3 and 4 show the result of the annual greenhouse gas emissions for the conventional scenario and the proposed plant respectively.

Table 3. Greenhouse gases emission for the conventional plant.

\begin{tabular}{ccccc}
\hline Type of Fuel & Fuel Mix & $\begin{array}{c}\text { Fuel Consumption } \\
\text { (MWh) }\end{array}$ & $\begin{array}{c}\text { Greenhouse Gases Emission Per MWh } \\
\left.\text { (ton } \mathbf{C O}_{2} / \mathbf{M W h}\right)\end{array}$ & $\begin{array}{c}\text { Greenhouse Gas Emission } \\
\text { (ton CO} \mathbf{~})\end{array}$ \\
\hline Natural gas & $12.8 \%$ & 31 & 0.197 & 6.1 \\
Electrical energy & $87.2 \%$ & 210 & 0.374 & 78.6 \\
Total & $100 \%$ & 241 & 0.351 & 84.7 \\
\hline
\end{tabular}

Table 4. Greenhouse gas emission for the proposed plant.

\begin{tabular}{ccccc}
\hline Type of Fuel & Fuel Mix & $\begin{array}{c}\text { Fuel Consumption } \\
\text { (MWh) }\end{array}$ & $\begin{array}{c}\text { Greenhouse Gases Emission per MWh } \\
\left.\text { (ton } \mathbf{C O}_{2} / \mathbf{M W h}\right)\end{array}$ & $\begin{array}{c}\text { Greenhouse Gas Emission } \\
\text { (ton } \mathbf{C O}_{2} \text { ) }\end{array}$ \\
\hline Biomass & $13.9 \%$ & 34 & 0.007 & 0.2 \\
Solar energy & $18.2 \%$ & 44 & 0.000 & 0.0 \\
Electrical energy & $67.8 \%$ & 163 & 0.374 & 61.0 \\
Total & $100 \%$ & 240 & 0.255 & 61.2 \\
\hline
\end{tabular}

It is worth noticing that, despite a comparable energy fuel consumption employing the proposed plant, a significant reduction of greenhouse gas emissions can be assessed. Indeed, the suggested system emits 23.5 tons of $\mathrm{CO}_{2}$ less than the conventional one.

\subsection{Thermal Comfort Model}

Taking into account a single flat of the fourth floor of the RhOME for denCity project, an analysis of thermal comfort for three rooms was carried out. The aim of this study is to investigate the impact of the house ventilation system on the thermal comfort inside the rooms. The study includes: The bedroom, the living room and the kitchen, as shown in Figure 9. 
A different FEM (Finite Elements Method) analysis was performed within a 3D domain [31-34]. The model is coupled with TRNSYS simulations. As a matter of fact, conditions of walls and windows are settled according to the variation taken from the TRNSYS output for two reference days: the hottest day in summer (13 July) and the coldest day in winter (11 January). The modelled system is composed of two air inlets in the living room and four air outlets in the bathroom, in the kitchen and in the corridor between the kitchen and the entrance. The inflow and outflow is shown in Figure 10.

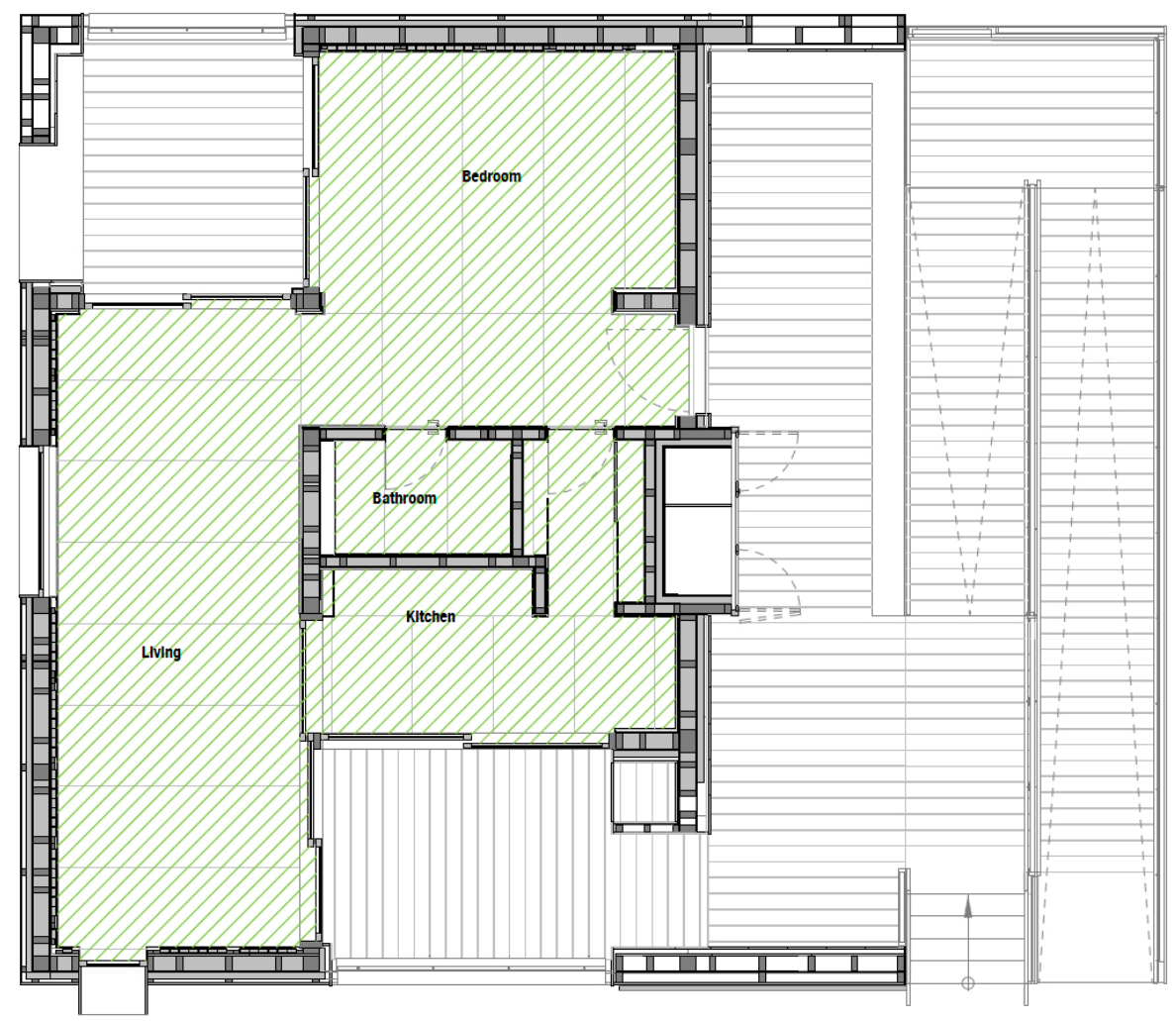

Figure 9. Planimetry of the isolated house.

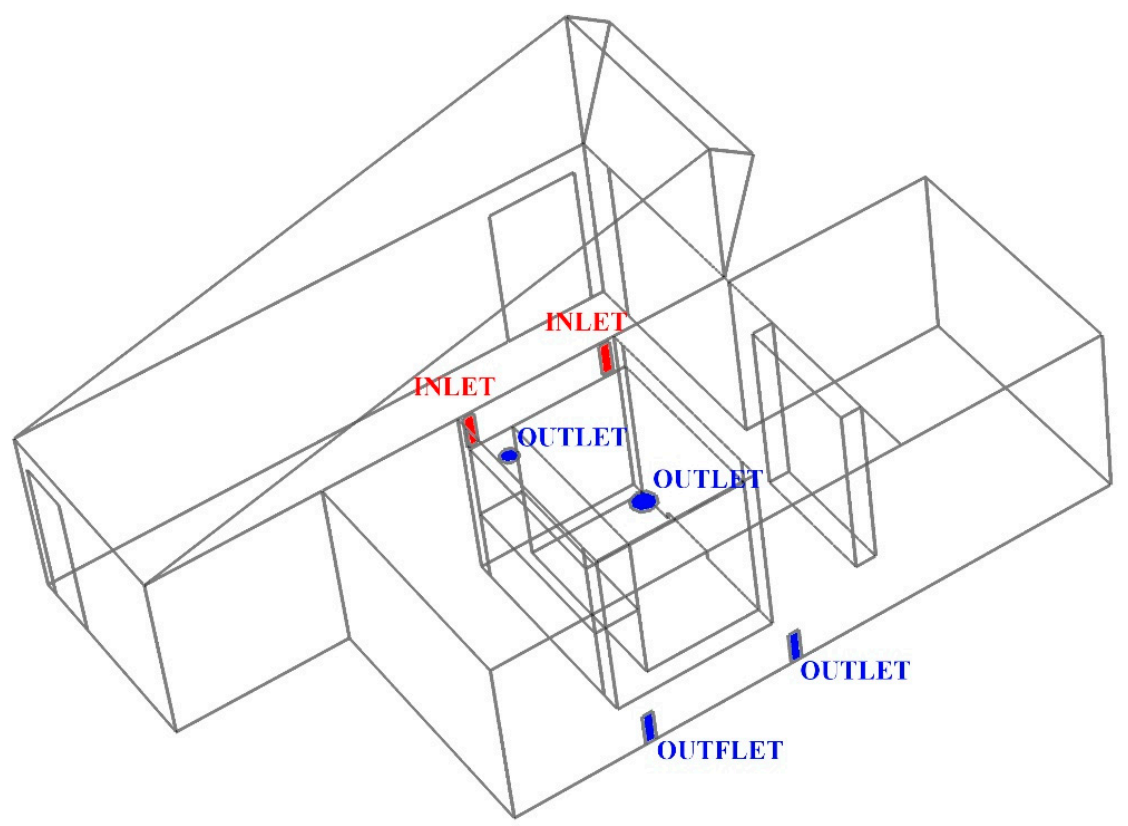

Figure 10. Position of the air inlets and the air outlets of the system. 
The mesh of the model is composed of tetrahedral cells. The mesh is denser near the air outlets or inlets. The choice of the best model mesh is the outcome of several simulations in order to achieve the convergence of Reynold numbers inside the computational domain. The final model is composed of 242,886 elements with the average mesh quality of 0.7644 . The mesh quality provides the geometrical distortion of a cell through the spatial difference between the cell nodes (for instance an "ideal" 2D cell is characterised by an equilateral triangle or a square). It is worth noticing that the given mesh quality value is good for a fluid dynamic computational model. The 3D model is shown in Figure 11.

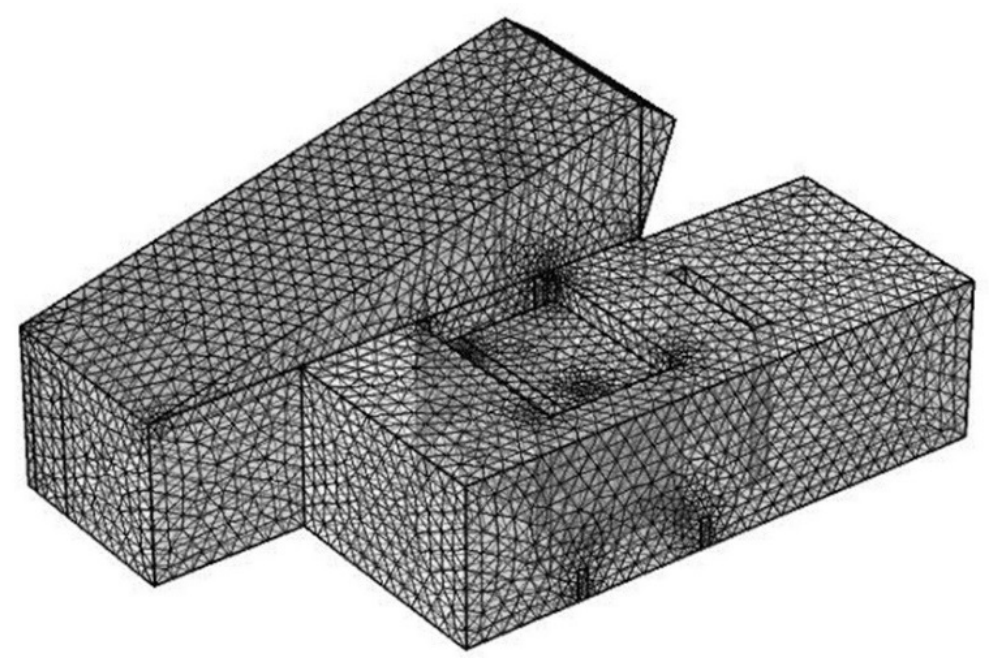

Figure 11. Computational 3D domain.

Results and Discussions

The aim of this study is to evaluate the average velocity and temperature values in the considered areas: the bedroom, the living room and the kitchen. The simulation areas for the three rooms are shown in Figure 12.
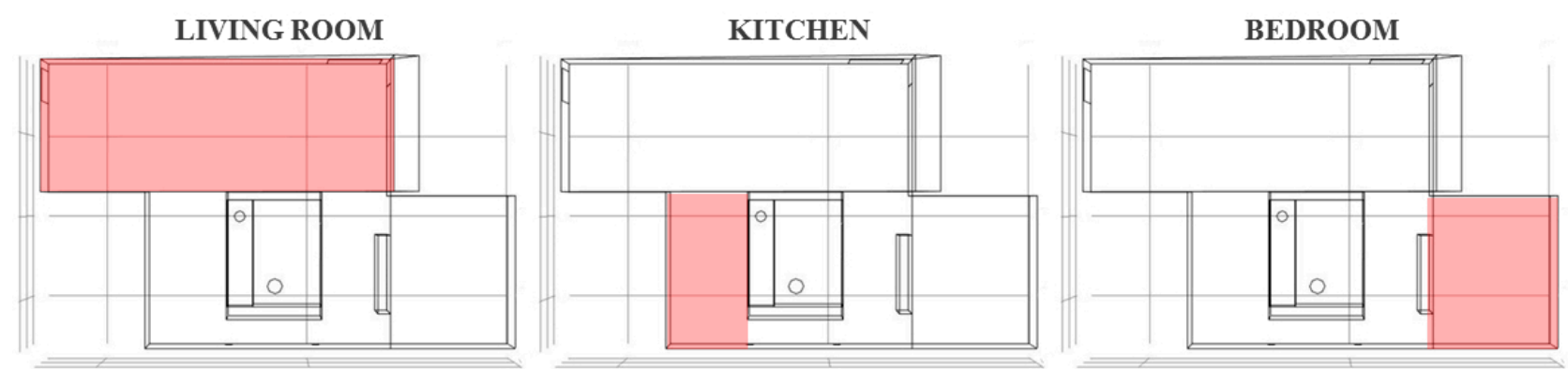

Figure 12. Simulation areas.

Table 5 shows the values of average velocity and temperature evaluated in the simulation areas during the days taken into account.

The velocity and temperature values at the simulation areas are compared with the Italian Standard Reference UNI 10339 [35] where the permissible speed variation for residential buildings ranges from 0.05 to $0.15 \mathrm{~m} / \mathrm{s}$ with a temperature variation of $26 \pm 1{ }^{\circ} \mathrm{C}$ during summer and $20 \pm 1{ }^{\circ} \mathrm{C}$ during winter. These 
values refer to a conventional volume, which is the result of the floor and a height of $1.8 \mathrm{~m}$. The velocity and temperature values, both for summer and winter, are in agreement with the Standard Reference.

Table 5. Average velocity and temperature values for the different simulation areas.

\begin{tabular}{ccccc}
\hline \multirow{2}{*}{ Rooms } & \multicolumn{2}{c}{ Summer } & \multicolumn{2}{c}{ Winter } \\
\cline { 2 - 5 } & Velocity $(\mathbf{m} / \mathbf{s})$ & Temperature $\left({ }^{\circ} \mathbf{C}\right)$ & Velocity $(\mathbf{m} / \mathbf{s})$ & Temperature $\left({ }^{\circ} \mathbf{C}\right)$ \\
\hline Living Room & 0.12 & 25.0 & 0.15 & 20.6 \\
Kitchen & 0.07 & 25.2 & 0.13 & 20.5 \\
Bedroom & 0.05 & 25.4 & 0.12 & 20.2 \\
\hline
\end{tabular}

It is worth noticing that the values slightly worsen in the bedroom despite of the other rooms. This is due to the need to install a compacted ventilation system in the bathroom area and for the presence of a wall inside the bedroom, which is an obstacle to the ventilation. As a matter of fact, the air vent position is the result of studies able to identify the best airflow direction in order to maximize the thermal comfort inside the rooms.

In Figure 13, the temperature and velocity field, and the streamline of the flow field are superimposed in the summer day. Two fluid-dynamic large scale, forced by air inlets, are trapped in the living room. The temperature mixing in the flow domain leads to the fluid-dynamic field, so the temperature inhomogeneity can be ascribed to the coupled of vortex located in the living room. This phenomenon is due to the geometry of the living room, which is close enough to a partial rectangular enclosure deeply investigated in fluid-dynamics, among many [36].
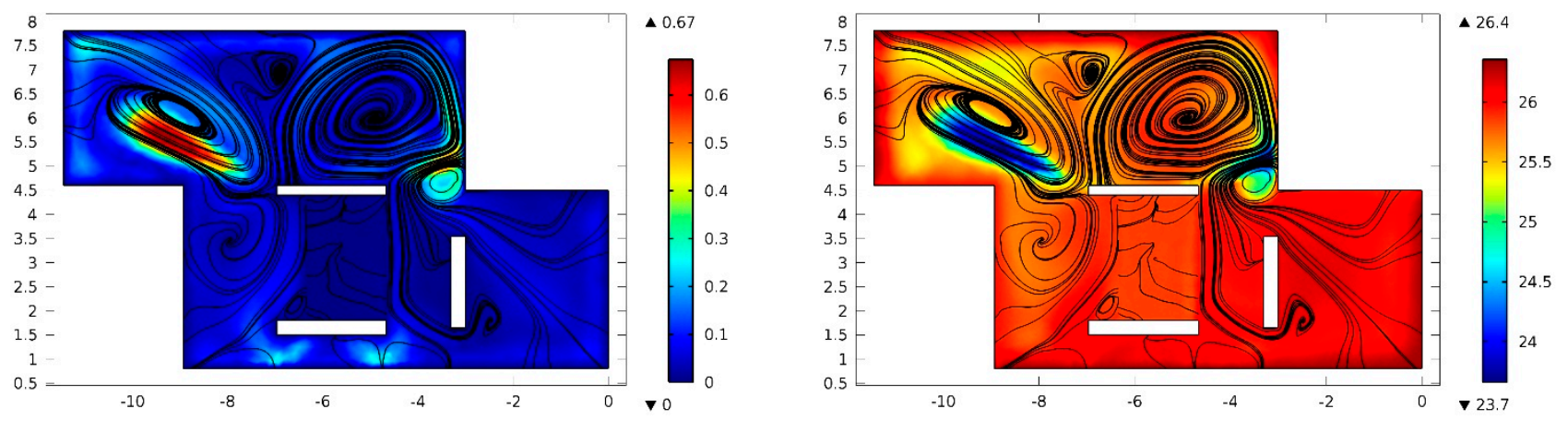

Figure 13. Temperature and velocity field with streamline of the flow field on a summer day.

\section{Conclusions}

The paper presents an overview of the contribution of L.I.F.T. (Interdisciplinary Laboratory of Technical Physics) in the RhOME for denCity project, the winner of the Solar Decathlon 2014 Europe contest. The project goal was to achieve a solar-powered house that is cost-effective, energy-efficient, and attractive.

The first study concerns the energy demand and the best plant configuration analysis for a building composed by eight innovative apartments designed with the same characteristics of the house presented in the RhOME for denCity project. The building was analysed through the TRNSYS software, which is able to calculate thermal loads with a dynamic approach. Afterwards, in order to perform an energy, environmental and financial assessment integrated with an investment, operation 
and maintenance cost analysis, RETScreen software was used to define economic intervention benefits. The proposed plant — composed of a heat pump for the cooling demand, a photovoltaic plant for the electrical demand and a pellet boiler for heating demand-allows one to avoid the fossil fuels with a consequent reduction of the greenhouse gas emissions of about $28 \%$ per year. In particular, by employing the proposed system, the $\mathrm{CO}_{2}$ emissions have been decreased by 23.5 tons per year if compared to a plant conventionally used in a residential district building. Furthermore, the return on investments is calculated in 5 years with a cash flow after the 15 th project year higher than $350,000 €$.

The second study concerns the assessment of the thermal comfort in different simulation points for three rooms of the innovative RhOME for denCity house. The analysis, integrated with the TRNSYS output, leads to a temperature variation from 20.2 to $20.6{ }^{\circ} \mathrm{C}$ in winter and from 25 to $25.4{ }^{\circ} \mathrm{C}$ in summer, and a velocity variation from 0.12 to $0.15 \mathrm{~m} / \mathrm{s}$ in winter and from 0.05 to $0.12 \mathrm{~m} / \mathrm{s}$ in summer, in agreement with the Italian Standard Reference UNI 10339.

The numerical simulations give an interesting idea of the significant role of the walls in terms of the convection of temperature in the region investigated. In our next work, the author will investigate other walls' configurations in order to optimize the recirculation of the air conditioning in the building.

\section{Acknowledgments}

The authors would like to thank the other members of the RhOME for denCity team.

\section{Author Contributions}

The work was designed by Gabriele Battista, Emiliano Carnielo and Roberto de Lieto Vollaro. Luca Evangelisti collected and organised the building envelope data and the literature related to the research. Model design and numerical analyses were carried out by Gabriele Battista and Emiliano Carnielo. English corrections were revised by Emiliano Carnielo. Finally, Roberto de Lieto Vollaro and Marco Frascarolo, the full professors of the research group, supervised the work related to the paper and the execution of its various phases.

\section{Conflicts of Interest}

The authors declare no conflict of interest.

\section{References}

1. Kjärstad, J.; Johnsson, F. Resources and future supply of oil. Energy Policy 2009, 37, 441-464.

2. Kamal, W. Improving energy efficiency-The cost-effective way to mitigate global warming. Energy Convers. Manag. 1997, 38, 39-59.

3. Ürge-Vorsatz, D.; Eyre, N.; Graham, P.; Harvey, D.; Hertwich, E.; Jiang, Y.; Kornevall, C.; Majumdar, M.; McMahon, J.E.; Mirasgedis, S.; et al. Chapter 10-Energy End-Use: Building. In Global Energy Assessment-Toward a Sustainable Future; Cambridge University Press: Cambridge, UK, 2012; pp. 649-760.

4. Lior, N. Energy resources and use: The present situation and possible paths to the future. Energy 1997, 33, 842-857. 
5. Directive 2010/31/EU of the European Parliament and of the Council of 19 May 2010 on the energy performance of buildings (recast). Available online: http://www.buildup.eu/sites/default/ files/content/EPBD2010_31_EN.pdf (accessed on 15 July 2015).

6. Voss, K.; Musall, E.; Lichtmeß, M. From low energy to net zero energy buildings-Status and perspectives. J. Green Build. 2011, 6, 46-57.

7. King, R.J.; Warner, C. Solar decathlon: Energy we can live with. In Proceedings of the 3rd World Conference on Photovoltaic Energy Conversion IEEE, Osaka, Japan, 11-18 May 2003; Volume 3, pp. 2139-2142.

8. Wang, N.; Esram, T.; Martinez, L.A.; McCulley, M.T. A marketable all-electric solar house: A report of a Solar Decathlon project. Renew Energy 2009, 34, 2860-2871.

9. Warner, C.L.; Wassmer, M.R. Solar decathlon 2005 e PV system strategies and results. In Proceedings of the 4rd World Conference on Photovoltaic Energy Conversion IEEE, Waikoloa, HI, USA, 7-12 May 2006; Volume 34, pp. 2272-2276.

10. Warner, C.L.; King, R.; Nahan, R.; Eastment, M. Solar decathlon: Collegiate challenge to build the future. In Proceedings of the 29th IEEE Photovoltaic Specialists Conference, New Orleans, LA, USA, 19-24 May 2002; pp. 44-48.

11. Hayter, S.; Nahan, R.; Stafford, B.; Warner, C.; Hancock, E.; Howard, R. Solar Decathlon 2002: The Event in Review; U.S. Dept. of Energy, Energy Efficiency and Renewable Energy: Washington, DC, USA, 2004.

12. Peng, C.; Huang, L.; Liu, J.; Huang, Y. Energy performance evaluation of a marketable net-zero-energy house: Solark I at Solar Decathlon China 2013. Renew. Energy 2004, 81, 136-149.

13. Solar Decathlon Europe 2014. Available online: http://www.solardecathlon2014.fr/en/ (accessed on 15 July 2015).

14. RhOME for Dencity. Available online: http://www.rhomefordencity.it/SDE/ (accessed on 15 July 2015).

15. De Lieto Vollaro, R.; Calvesi, M.; Battista, G.; Evangelisti, L.; Botta, F. Calculation model for optimization design of low impact energy systems for buildings. Energy Procedia 2014, 48, 1459-1467.

16. De Lieto Vollaro, R.; Evangelisti, L.; Battista, G.; Gori, P.; Guattari, C.; Fanchiotti, A. Bus for urban public transport: Energy performance optimization. Energy Procedia 2014, 45, 731-738.

17. Peruzzi, L.; Salata, F.; de Lieto Vollaro, A.; de Lieto Vollaro, R. The reliability of technological systems with high energy efficiency in residential buildings. Energy Build. 2014, 68, 19-24.

18. Battista, G.; Evangelisti, L.; Guattari, C.; Basilicata, C.; de Lieto Vollaro, R. Buildings Energy Efficiency: Interventions Analysis under a Smart Cities Approach. Sustainability 2014, 6, 4694-4705.

19. De Lieto Vollaro, R.; Evangelisti, L.; Carnielo, E.; Battista, G.; Gori, P.; Guattari, C.; Fanchiotti, A. An Integrated Approach for an Historical Buildings Energy Analysis in a Smart Cities Perspective. Energy Procedia 2014, 45, 372-378.

20. Evangelisti, L.; Battista, G.; Guattari, C.; Basilicata, C.; de Lieto Vollaro, R. Analysis of Two Models for Evaluating the Energy Performance of Different Buildings. Sustainability 2014, 6, 5311-5321.

21. De Lieto Vollaro, R.; Guattari, C.; Evangelisti, L.; Battista, G.; Carnielo, E.; Gori, P. Building energy performance analysis: A case study. Energy Build. 2015, 87, 87-94. 
22. Zinzi, M.; Carnielo, E.; Federici, A. Preliminary studies of a cool roofs' energy-rating system in Italy. Adv. Build. Energy Res. 2014, 8, 84-96.

23. Zinzi, M.; Carnielo, E.; Agnoli, S. Characterization and assessment of cool coloured solar protection devices for Mediterranean residential buildings application. Energy Build. 2012, 50, 111-119.

24. Carnielo, E.; Zinzi, M. Optical and thermal characterisation of cool asphalts to mitigate urban temperatures and building cooling demand. Build. Environ. 2013, 60, 56-65.

25. Salata, F.; de Lieto Vollaro, A.; de Lieto Vollaro, R.; Davoli, M. Plant reliability in hospital facilities. Energy Procedia 2014, 45, 1195-1204.

26. Coppi, M.; Quintino, A.; Salata, F. Numerical study of a vertical channel heated from below to enhance natural ventilation in a residential building. Int. J. Vent. 2013, 12, 41-49.

27. Salata, F.; de Lieto Vollaro, A.; de Lieto Vollaro, R.; Mancieri, L. Method for energy optimization with reliability analysis of a trigeneration and teleheating system on urban scale: A case study. Energy Build. 2015, 86, 118-136.

28. Salata, F.; Golasi, I.; de Lieto Vollaro, A.; de Lieto Vollaro, R. How high albedo and traditional buildings' materials and vegetation affect the quality of urban microclimate. A case study. Energy Build. 2015, 99, 32-49.

29. Evangelisti, L.; Battista, G.; Guattari, C.; Basilicata, C.; de Lieto Vollaro, R. Influence of the Thermal Inertia in the European Simplified Procedures for the Assessment of Buildings' Energy Performance. Sustainability 2014, 6, 4514-4524.

30. Salata, F.; de Lieto Vollaro, A.; de Lieto Vollaro, R. A case study of technical and economic comparison among energy production systems in a complex of historic buildings in Rome. Energy Procedia 2014, 45, 482-491.

31. Bottillo, S.; de Lieto Vollaro, A.; Galli, G.; Vallati, A. CFD modeling of the impact of solar radiation in a tridimensional urban canyon at different wind conditions. Sol. Energy 2014, 102, 212-222.

32. Bottillo, S.; de Lieto Vollaro, A.; Galli, G.; Vallati, A. Fluid dynamic and heat transfer parameters in an urban canyon. Sol. Energy 2014, 99, 1-10.

33. De Lieto Vollaro, A.; de Simone, G.; Romagnoli, R.; Vallati, A.; Bottillo, S. Numerical Study of Urban Canyon Microclimate Related to Geometrical Parameters. Sustainability 2014, 6, 7894-7905.

34. De Lieto Vollaro, R.; Vallati, A.; Bottillo, S. Differents Methods to Estimate the Mean Radiant Temperature in an Urban Canyon. Adv. Mater. Sci. Eng. 2013, 650, 647-651.

35. UNI 10339-Air systems for thermal comfort (In Italian: Impianti aeraulici a fini di benessere). Available online: http://www.repertoriosalute.it/wp-content/uploads/2015/03/UNI-10339impianti-aeraulici.pdf (accessed on 16 July 2015).

36. Pagliaroli, T.; Camussi, R. Wall pressure fluctuations in rectangular partial enclosures J. Sound Vib. 2015, 341, 116-137.

(C) 2015 by the authors; licensee MDPI, Basel, Switzerland. This article is an open access article distributed under the terms and conditions of the Creative Commons Attribution license (http://creativecommons.org/licenses/by/4.0/). 